\title{
New report of Anikasis larvae from Blunthead Puffer, Spho- eroides pachygaster caught off Strait of Sicily
}

\author{
Gaetano Cammilleri', Stefania Graci', Maria Drussilla Buscemi', Rosaria Collura',Antonella Costa', Gian- \\ luigi Maria Lo Dico', Francesca Ornella Assiria', Michele Chetta', Innocenzo Ezio Giangrosso', Francesco \\ Giuseppe Galluzzo',Valentina Cumbo',Antonio Vella', Andrea Pulvirenti² \& Vincenzo Ferrantelli' \\ ${ }^{1}$ Centro di Referenza Nazionale Anisakiasi (C.Re.N.A), Istituto Zooprofilattico Sperimentale della Sicilia “A. Mirri”, Via G. Ma- \\ rinuzzi 3, 90129 Palermo, Italy \\ ${ }^{2}$ Dipartimento di Scienze della Vita, Università degli studi di Modena e Reggio Emilia, Via Università 124, 41121 Modena, Italy
}

ABSTRACTS

\begin{abstract}
Aim of the present paper was to report and identify by morphological and molecular methods the presence of anisakid L3 larvae found in 7 specimens of Sphoeroides pachygaster caught off Strait of Sicily from 2012 and 2015. Nematode larvae $(n=9)$ were collected from three fish samples: the larvae were morphologically identified as belonging to the genus Anisakis Type I and, stored in 70\% ethanol, were underwent molecular identification at species level by PCR- RFLP analysis of the rDNA (ITS-1, 5.8S gene, and ITS-2) region. Sequencing of ITS regions and comparison with sequences in GenBank were also performed. The parasites were molecular identified as belonging to $A$. pegreffii that is the predominant species in Mediterranean Sea. This is a new report of Anisakis sp. in S. pachygaster. The blunthead puffer Sphoeroides pachygaster is a fish species of Atlantic origin: in the last years there are indeed numerous reports of this alien fish species in the Mediterranean included Italian Seas. The presence of the species Anisakis pegreffii may support the hypothesis of complete adaptation of S. pachygaster in the Mediterranean Sea.
\end{abstract}

KEY WORDS

Anisakis; PCR-RFLP; nematodes.

Received 22.11.2019; accepted 10.12.2019; published online 20.12.2019

Proceedings of the 4th International Congress on Biodiversity "Man, Natural Habitats and Euro-Mediterranean Biodiversity", November 17th-19th, 2017 - Malta

\section{INTRODUCTION}

The blunthead puffer Sphoeroides pachygaster (Müller \& Troschel, 1848) is widely distributed in tropical and temperate waters on both sides of the Atlantic Ocean (Shipp, 1990). The species is known in the Mediterranean Sea where in the last years several records were reported (Cherif et al., 2010; Hemida et al., 2009; Relini et al., 1995) included Italian Seas (Adriatic Sea, Tyrrhenian Sea, Ionian Sea, Sicilian Channel) (Vacchi \& Cau, 1986; Arculeo et al., 1994; Giordano et al., 2012; Ragonese et al., 1997; Tursi et al., 1992; Ligas et al., 2006; Visentin \& Borg, 2014). The presence of this alien species in the Mediterranean has been ascribed to the migration or casual transport through the Strait of Gibraltar and the Suez Canal; the spread is caused and favored by the ongoing phenomen of global warming (Massuti et al., 2010). Actually it is believed that $S$. pachygaster form a well established population in the Mediterranean Sea, with local reproduction, because of the discovery of young and adult specimens (Lipej et al., 2013; Ragonese et al., 2001). 
There are not reported in the literature reports of parasitic nematodes of the Anisakidae family in blunthead puffer. This paper reports a parasitological survey of $\mathrm{n} .7$ specimens of this fish species, caught off Strait of Sicily, indicating at the same time for the first time the presence of nematode larvae of Anisakis sp.

\section{MATERIAL AND METHODS}

Fish samples were collected in the Strait of Sicily, in front of the Agrigento coast, during trawl surveys, from 2012 and 2015: 7 specimens of $S$. pachygaster were caught accidentally by fishing vessels. The specimens were transported refrigerated at the C.I.S.S. of the University of Messina and were identified, measured and weighted (Fig. 1).

On the studied fish, a parasitological exam was performed examining the coelomic cavity for metazoan parasites, by visual and stereoscopic inspection. Nematode larvae were collected, washed in saline solution, fixed in $70 \%$ ethanol and cleared with glycerol for morphological identification by light microscopy (Berland, 1961) (Fig. 3). The larvae, identified according to morphological characters as belonging to the genus Anisakis, were stored in $70 \%$ ethanol for underwent molecular identification at species level by PCR- RFLP analysis of the rDNA (ITS-1, 5.8S gene, and ITS-2) region using two restriction enzymes, HinfI and HhaI, for the identification of Anisakis spp. (D'Amelio et al., 2000; Pontes et al., 2005) (Fig. 4). Purification of ITS gene amplification products was carried out with Illustra GFX PCR DNA and Gel Band Purification kit (GE Healthcare) following the manufacturer's instructions. The purified products were sent to Macrogen company (Amsterdam, Holland) for Sanger sequencing. The morphological and molecular identification of the parasites were performed by the C.Re.N.A. of IZS of Palermo (Italy).

\section{RESULTS AND DISCUSSION}

The results are reported in Table 1. Nematoda larvae $(n=9)$ were isolated in the coelomic cavity of 3 samples of S. pachygaster. Analysis of the morphological characteristics, observed by light microscopy, allowed to identify the parasites as Anisakis larvae Type I (sensu Berland, 1961) (Fig. 3). In the molec-

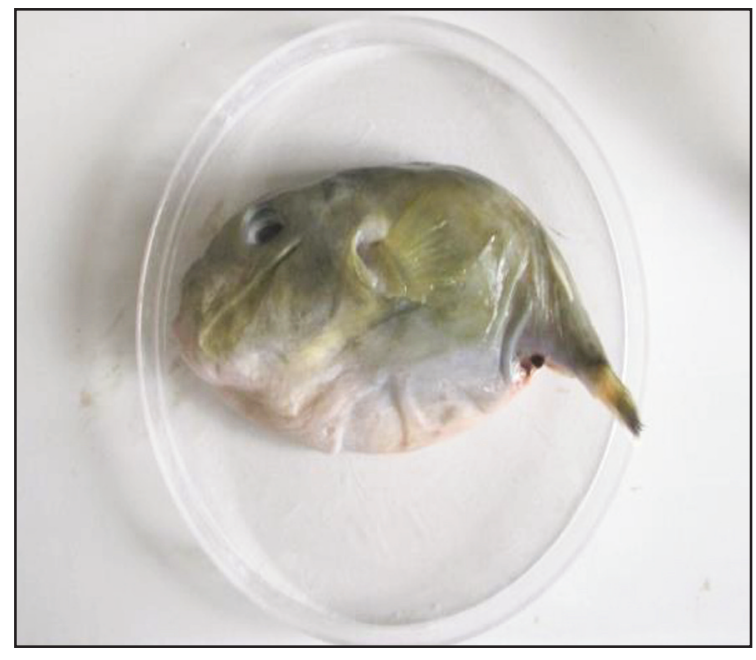

Figure 1. Sphoeroides pachygaster.

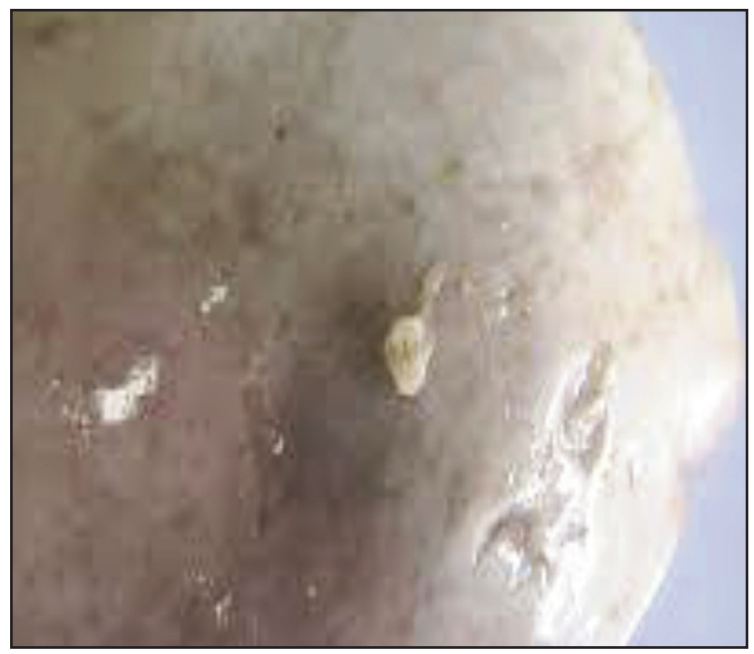

Figure 2. One larva encapsulated on the liver.

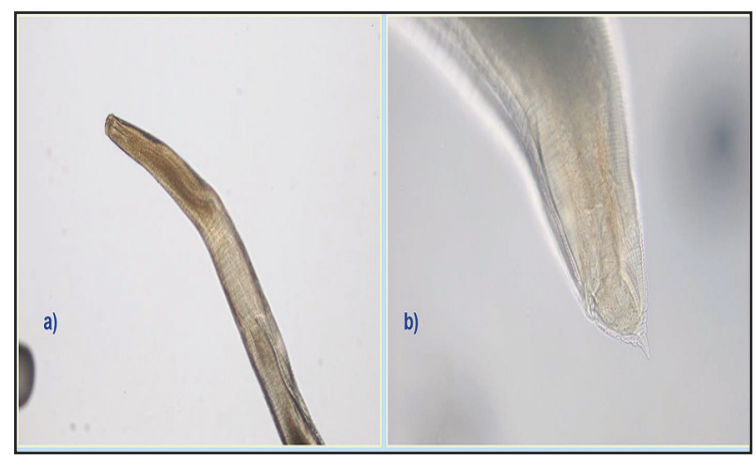

Figure 3. Anisakis larva Type I: a) anterior extremity b) tail showing mucron 


\begin{tabular}{|c|c|c|c|c|c|c|c|}
\hline year & $\begin{array}{l}\text { Samples } \\
\text { n. }\end{array}$ & $\begin{array}{l}\text { Weight } \\
\text { g }\end{array}$ & Locality & $\begin{array}{l}\text { Presence of } \\
\text { parasites }\end{array}$ & $\begin{array}{l}\text { Larvae } \\
\text { isolated }\end{array}$ & $\begin{array}{l}\text { Morphological } \\
\text { identification }\end{array}$ & $\begin{array}{l}\text { Molecular } \\
\text { identification } \\
\text { (PCR-RFLP) }\end{array}$ \\
\hline 2012 & 1 & 1750 & Strait of Sicily & 1 & 2 & Anisakis Tipo I & A. pegreffii \\
\hline 2015 & 2 & 560 & Strait of Sicily & 1 & 3 & Anisakis Tipo I & A. pegreffii \\
\hline 2015 & 3 & 940 & Strait of Sicily & 1 & 4 & Anisakis Tipo I & A. pegreffii \\
\hline 2015 & 4 & 730 & Strait of Sicily & - & - & - & - \\
\hline 2015 & 5 & 420 & Strait of Sicily & - & - & - & - \\
\hline 2015 & 6 & 385 & Strait of Sicily & - & - & - & - \\
\hline 2015 & 7 & 130 & Strait of Sicily & - & - & - & - \\
\hline Totale & 7 & & & 3 & 9 & & \\
\hline
\end{tabular}

Table 1. Results of fish examined, year, weight and fishing locality.
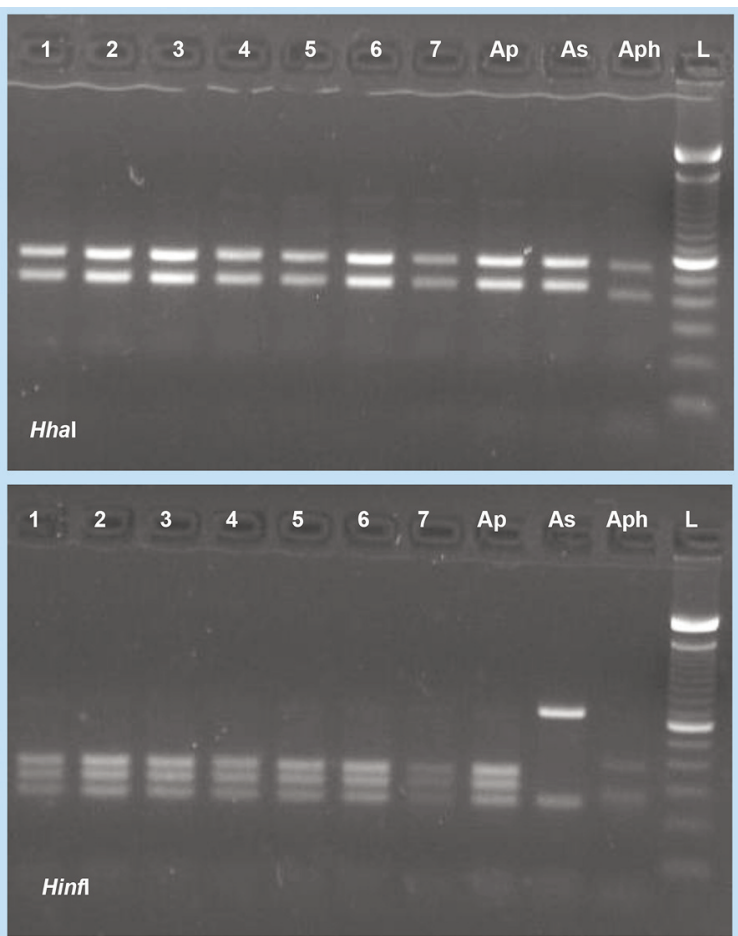

Figure 4. RFLP patterns obtained by digestion of the ITS region with the restriction enzymes Hha I and Hinf I. Lanes 1 7: Anisakis pegreffii (17), positive controls: Ap: A. pegreffii, A. simplex s.s., Aph: A. physeteris L: 100 bp ladder. ular identification with PCR-RFLP analysis, the specific restriction profiles obtained were allowed to identify anisakid parasites as Anisakis pegreffii, according to the taxonomical keys available in literature (D'Amelio et al., 2000; Pontes et al., 2005). The sequences obtained were aligned and compared with the sequences deposited in GenBank, showing a 99\% of identity with reference sequences of $A$. pegreffii (AY826720). Anisakis pegreffii is the predominant species in Mediterranean Sea while A. simplex s.s. is found in fish species of Atlantic Sea. The blunthead puffer S. pachygaster is a fish species of Atlantic origin, spread in all seas and oceans, warm and temperate. This alien species is known in the Mediterranean Sea where represent a definitively estabilished population. The discovery of anisakid nematodes and identification of species such as $A$. pegreffii, may support the hypothesis of complete adaptation of $S$. pachygaster as well as of existence of a Mediterranean population.

\section{REFERENCES}

Berland B., 1961. Nematodes from some Norwegian marine fishes, Sarsia, 2: 1-50. 
Arculeo M., Riggio S. \& D’Anna G., 1994. First record of Sphoeroides pachygaster (Tetraodontidae) in the south Tyrrhenian (N/W Sicily) Cybium, 18: 208209.

Chérif M., Ben Amor M.M., Bdioui M., Ben Salem S., Missaoui H. \& Capapé H., 2010. Additional records of theblunthead puffer, Sphoeroides pachygaster (Osteichthyes: Tetraodontidae) off the Tunisian coast (CentralMediterranean). Annales, Series Historia Naturalis Archives, 20: 33-36.

D'Amelio S., Mathiopoulosa K.D., Santos C.P., Pugachevc O.N., Webb S.C., Picanço M. \& Paggia L., 2000. Genetic markers in ribosomal DNA for the identification of members of the genus Anisakis (Nematoda: Ascaridoidea) defined by polymerase-chainreaction-based restriction fragment length polymorphism. International Journal for Parasitology, 30: 223-226. https://doi.org/10.1016/s0020-7519 (99)00178-2

Giordano D., Profeta A., Pirrera L., Soraci F., Perdichizzi F., Greco S., Perdichizzi A. \& Rinelli P., 2012. On the occurrence of the blunthead puffer, Sphoeroides pachygaster (Osteichthyes: Tetraodontidae), in the Strait of Messina (Central Mediterranean). Journal of Marine Biology, Article ID 462407, 3 pages. http:// dx.doi.org/10.1155/2012/462407

Hemida F., Mourad M., Ben-Amour M.M. \& Capapé C., 2009. First confirmed record of the blunthead puffer, Sphoeroides pachygaster (Osteichthyes: Tetraodontidae) off the Algerian coast (south-western Mediterranean). Pan-American Journal of Aquatic Sciences, 4: 188-192.

Ligas A., Sirna R. \& Sartor R., 2006. Prima segnalazione di Sphoeroides pachygaster (Muller \& Troschel, 1848) (Pisces, Tetraodontidae) nel Mar Tirreno Settentrionale. Biologia Marina Mediterranea, 13, 274-275.

Lipej L., Mavrič B. \& Paliska D., 2013. New Northernmost record of the blunthead pufferfish Sphoeroides pachigaster (Osteichthyes: Tetraodontidae) in the Mediterranean Sea. Annales, Series Historia Naturalis, 23: 103-111.
Massuti E., Valls M. \& Ordines F., 2010. Changes in the western Mediterranean ichthyofauna: signs of tropicalisation and meridianizations. In: Golani D. \& Appelbaum-Golani B. (Eds.), Fish invasions of the Medi-terranean Sea: Change and renewal. Pensoft Publishers, Sofia-Moscow, pp. 293-312.

Pontes T., D’Amelio S., Costa G. \& Paggi E., 2005. Molecular characterization of larval anisakid nematodes from marine fishes of Madeira by a PCR-based approach, with evidence for a new species. Journal of Parasitology, 91: 1430-1434. http:// dx.doi.org/10. 1645/GE-565R1.1

Ragonese S., Jereb P. \& Morara U., 1997. Morphometric relationships of Sphoeroides pachygaster (Pisces: Tetraodontidae) of the Strait of Sicily (Mediterranean Sea). Cahiers de Biologie Marine, 38: 283-289.

Ragonese S., Caltagirone P. \& Jereb P., 2001. Observations on reproduction and fecundity of Sphoeroides pachygaster (Pisces-Tetraodontidae) from the $\mathrm{Si}$ cilian Channel (Mediterranean Sea). Rapports et Procés-Verbaux des Réunions de la Commission Internationale pour l'Exploration Scientifique de la Mer Méditerranée, 36: 313.

Relini M. \& Orsi Relini L., 1995. Pesci palla in Mediterraneo, presenze antiche e recenti. Biologia Marina Mediterranea, 2: 509-511.

Shipp R.L., 1990. Tetraodontidae. In: Quéro J.C., Ureau J.C.H., Karrer C., Post A. \& Saldanha L. (Eds.), Check-List of the Fishes of the Eastern Tropical Atlantic, UNESCO, Paris, France.

Tursi A., D’Onghia G. \& Matarrese A., 1992. First finding of Sphoeroides pachygaster (Muller \& Troschel, 1848) (Tetraodontidae) in the Ionian Sea (middle eastern Mediterranean). Cybium, 16: 171-172.

Vacchi M.A. \& Cau 1986. The occurrence of Sphoeroides cutaneus (Günther 1870) (Pisces, Tetraodontidae) in the middle-west Mediterranean Sea. Cybium, 10: 199-203.

Visentini M. \& Borg J.J., 2014. Rinvenimento di Sphoeroides pachygaster (Muller \& Troschel, 1848) (Pisces, Tetraodontidae) in Calabria e a Malta. Il Naturalista siciliano, 38: 89-92. 